\title{
Physicochemical Characteristics and Lipid Oxidation of Chicken Inner Fillets Subjected to Different Thermal Processing Types
}

-Author(s)

\author{
Arguelo NN' \\ Garcia ERM" \\ Ferreira de Lara JA"II \\ Ferraz ALJiv
}

Post-graduation Program in Animal Science of the State University of Mato Grosso do Sul, Aquidauana campus, Aquidauana, MS, Brazil.

" Professor, Post-graduation Program in Animal Science of the State University of Mato Grosso do Sul.

III Researcher, Empresa Brasileira de Pesquisa Agropecuária, EMBRAPA Pantanal, Corumbá, Mato Grosso do Sul, Brazil

Iv Professor, Post-graduation Program in Animal Science of the State University of Mato Grosso do Sul, Aquidauana campus, Aquidauana, MS, Brazil.

\section{Mail Address}

Corresponding author e-mail address Elis Regina de Moraes Garcia

Universidade Estadual de Mato Grosso do Sul, Unidade Universitária de Aquidauana - Rodovia Aquidauana/UEMS - Km 12 79.200-000 - Aquidauana, MS, Brasil Tel: $\quad$ (5567) 3904-2959

Email: ermgarcia@uems.br

\section{-Keywords}

Cooking, freezing, myofibrillar fragmentation index, lipid oxidation, reheating.

\section{ABSTRACT}

The objective of this study was to evaluate the effects of different types of thermal processing on the physiochemical characteristics and lipid oxidation of chicken inner fillets. The study was divided into three assays. In the first assay, 50 chicken inner fillets were divided into five treatments, totaling 10 samples per treatment. Treatments consisted in cooking in water bath, electric oven, microwave oven, deep frying, or grilling. The analyzed variables were: cooking weight loss $(\mathrm{CWL})$ and lipid oxidation determined by thiobarbituric acid reactive substances (TBARS). In the second assay, 50 chicken inner fillets were divided into five treatments, totaling 10 samples per treatment. Each treatment consisted of the same cooking methods applied in the first assay, and storage for 48 hours under refrigeration and reheating in a microwave oven. The variable analyzed in the second assay was lipid oxidation (TBARS). In the third assay, 30 samples of chicken inner fillets were subjected to one, four and eight freeze-thaw cycles, after which meat $\mathrm{pH}$, myofibrillar fragmentation index (MFI), water retention capacity (WRC), and lipid oxidation (TBARS) were determined. Chicken inner fillets submitted to deep frying and cooked in a microwave oven presented greater lipid oxidation than the other cooking methods, and deep frying resulted in the highest cooking weight loss. Reheating chicken inner fillets in a microwave oven caused the highest meat lipid oxidation. Increasing the number of freeze-thaw cycles increases the $\mathrm{pH}, \mathrm{MFI}, \mathrm{WRC}$ and TBARS values of chicken inner fillets.

\section{INTRODUCTION}

Brazilian poultry meat market has expanded consistently both domestically and worldwide. Today, Brazil is the leading global chicken meat exporter. However, the competitiveness of this market demands constant technological improvement, standardization, and particularly, strict product quality control (Brossi, 2007).

There is currently a significant demand for boneless chicken cuts, particularly for valuable cuts, such as breast and legs (Pavan et al., 2003). In this scenario, the inner fillet, known sometimes as the fillet mignon of chicken breast, has become popular in the market. This cut is found along the bone and cartilage of the breast, is small and elongated, white in color, low in fat and sold without skin (Lopes Comercial, 2014).

Thermal processing can alter the chemical composition of meat products. Among the different types of processing is cooking, the most commonly applied method for meat consumption. Cooking promotes the Maillard reaction, which is a conversion of collagen into gelatin, protein denaturation and can lead to changes in fats, resulting in a peculiar odor in each meat type (Bobbio \& Bobbio, 1995). 
Reheating is another heating method that can alter the chemical composition of pre-cooked meats due to the possible oxidation of polyunsaturated fatty acids, resulting in the development of warmed over flavor (WOF) (Pearson et al., 1977; Willemot et al., 1985). The development of undesirable aromas or flavors is a great challenge for meat processors due to the increasing demand for pre-cooked meats in recent decades (Luciano et al., 2009).

Another type of thermal processing that can cause positive and negative effects in meat products is freezing, which is used to preserve meat quality, both domestically and industrially. However, gradual losses in quality attributes may occur during storage under low temperatures, such as oxidation, osmotic release of water, and protein denaturation, adversely affecting the shelf life of frozen products (Benjakul et al., 2003). Among these changes, lipid oxidation is considered the main factor responsible for flavor deterioration and reduced shelf life of products due to the onset of peroxidation (Angelo et al., 2009).

Therefore, this study was conducted to evaluate the effects of different types of thermal processing on the physiochemical characteristics and lipid oxidation of chicken inner fillets.

\section{MATERIAL AND METHODS}

Three assays were performed between February and July 2014. Chilled chicken inner breast fillets from the same batch were obtained from a broiler processing plant, where inner fillets were placed in plastic containers (five per container), labeled, and frozen at $-18^{\circ} \mathrm{C}$ for 30 days until analyses. The three assays were conducted with different samples.

\section{Assay I}

In the first assay, 50 inner fillets were distributed in a completely randomized experimental design, with five treatments of 10 replicates each. Each treatment consisted of a cooking method and each inner fillet was regarded as one experimental unit.

The previously frozen samples were thawed, weighed (initial weight), and subjected to lipid oxidation analysis by the thiobarbituric acid reactive substances method (TBARS), according to the methodology described by Vyncke (1970).

For thawing, samples were arranged on a polyethylene tray, protected by a plastic film and kept in under refrigeration $\left(6^{\circ} \mathrm{C}\right)$ for 12 hours; therefore, all inner fillets were submitted to the same thawing conditions.
Samples were then individually submitted to one of following cooking methods:

a) Water bath (WB): samples were placed in polyethylene bags, and immersed in water preheated to $80^{\circ} \mathrm{C}$ for approximately six minutes until reaching $72^{\circ} \mathrm{C}$ internal temperature.

b) Electric oven (EO): samples were placed in a non-stick aluminum baking pan, and baked in an electric oven preheated to $150{ }^{\circ} \mathrm{C}$ for approximately six minutes until reaching $72^{\circ} \mathrm{C}$ internal temperature.

c) Microwave oven (MO): samples were placed in a glass bowl and cooked at maximum power for approximately two and a half minutes, until reaching $72^{\circ} \mathrm{C}$ internal temperature.

d) Deep frying (DF): samples were placed in a nonstick frying pan with $15 \mathrm{~mL}$ hot soybean oil $( \pm$ $160^{\circ} \mathrm{C}$ ), and turned once after one and a half minute, totaling three minutes of oil immersion, until reaching $72^{\circ} \mathrm{C}$ internal temperature. After frying, samples were placed on absorbent paper to remove oil excess and to cool down.

e) Grilling (GR): samples were placed on an electric grill preheated to $180^{\circ} \mathrm{C}$ for approximately eight minutes; each chicken inner fillet was turned once after approximately four minutes until reaching $72^{\circ} \mathrm{C}$ internal temperature.

The internal temperature of the individual samples was determined using a meat thermometer. The time and temperature used in each cooking method were determined in a previous assay.

After cooking, the samples were left to reach room temperature, placed on polyethylene trays and wrapped in plastic film, weighed (final weight), and again analyzed for lipid oxidation ( $\mathrm{mg}$ of malonaldehyde per $\mathrm{kg}$ of sample) using TBARS. In order to correct for the lipid oxidation values measured in the fresh samples, which might have been different at the time of commercial acquisition), lipid oxidation values were determined as the difference between malondialdehyde values obtained before and after cooking. Cooking weight loss (CWL) was calculated as the difference between initial and final weights.

\section{Assay II}

In the second assay, 50 inner fillets were distributed according to a completely randomized experimental design into five treatments of 10 replicates each. Each chicken inner fillet was considered as one experimental unit. After freezing, samples were thawed and submitted to the same cooking methods as described 
in the first assay, cooled to room temperature, and subjected to lipid oxidation analysis (Vyncke, 1970). Samples were then placed on polyethylene trays, wrapped in plastic film, and stored under refrigeration $\left(6^{\circ} \mathrm{C}\right)$ for 48 hours, after which they were reheated for four minutes in a microwave oven at high power, cooled to room temperature, and again analyzed for lipid oxidation (Vyncke, 1970).

Lipid oxidation was calculated as the difference between malondialdehyde values obtained in the cooked samples in assay I and after reheating in the microwave oven.

\section{Assay III}

In the third assay, 30 inner fillets were distributed according to a completely randomized design experimental into three treatments (freezing/thawing cycles) with 30 replicates of one chicken inner fillet each (experimental unit). Samples were wrapped, individually numbered, and subjected to three different freeze/thaw cycles, i.e., samples were frozen and thawed once, four, or eight times, as described below.

Firstly, samples were individually weighed in an analytical balance $( \pm 0.0001 \mathrm{~g})$ and longitudinally cut into three equal sections, each of which was submitted to a freeze/thaw cycle, and the remaining parts were returned to the freezer $\left(-18^{\circ} \mathrm{C}\right)$. After freezing, the samples were removed from the freezer in the afternoon and remained under refrigeration $\left(6^{\circ} \mathrm{C}\right)$ overnight until completely thawed. The next morning, the part to be analyzed was removed from the same samples and the other two were returned to the freezer for the second freezing cycle. The same procedure was adopted for the samples submitted to four and eight cycles.

The following parameters were analyzed in the samples submitted to the freeze/thaw cycles: $\mathrm{pH}$, myofibrillar fragmentation index (MFI) (Culler et al., 2009), water retention capacity (WRC) (Lakshmanan et al., 2007), and lipid oxidation (TBARS) (Vyncke, 1970).

Data were analyzed for normality using the ShapiroWilk test, and then submitted to analysis of variance. Means were compared by Tukey's test $(p \leq 0.05)$. All statistical analyses were carried out using SAS statistical software.

\section{RESULTS AND DISCUSSION}

The different cooking methods evaluated influenced $(p<0.05)$ of cooking weight loss (Table 1$)$ of the broiler inner fillets, with the lowest values observed by cooking in water bath (16.70\%) and in the microwave oven $(17.24 \%)$.
Table 1 - Initial weight (IW), final weight (FW), and mean cooking weight loss (CWL) values of chicken inner fillets subjected to different cooking methods.

\begin{tabular}{lccc}
\hline & IW $(\mathrm{g})$ & FW $(\mathrm{g})$ & $\mathrm{CWL}(\%)$ \\
\hline Water Bath & 33.26 & 27.68 & $16.70^{\mathrm{c}}$ \\
Electric Oven & 34.45 & 26.44 & $23.48^{\mathrm{b}}$ \\
Microwave Oven & 30.71 & 25.56 & $17.24^{\mathrm{c}}$ \\
Deep Frying & 34.21 & 24.07 & $30.11^{\mathrm{a}}$ \\
Grilling & 37.30 & 30.15 & $19.39^{\mathrm{bc}}$ \\
\hline Mean & - & - & 21.38 \\
\hline SEM & - & - & 0.88 \\
\hline
\end{tabular}

*Standard Error of the Mean. Means in the same row, followed by different lowercase letters, differ significantly by Tukey's test $(p \leq 0.05)$.

When using conventional heating forms (direct flame, hot air, direct contact with hot grill, and others) for cooking meat, heat sources cause the food molecules to heat up from the surface to the inside of the muscle mass, so that heating occurs in successive layers. Therefore, the outside layers of the cut are cooked first, i.e., the protein is coagulated, forming a film, which prevents the loss of meat components to the outside before its internal temperature rises, resulting in lower cooking loss (Potter \& Hotchkiss, 1995). On the other hand, in a microwave oven, heat is transferred by electromagnetic irradiation emitted by a warm body and absorbed by a cold body, increasing kinetic energy and causing thermal excitation. This promotes homogenous temperature distribution from the area where the temperature is high to where the temperature is low (Araújo, 1982). When food is cooked in a microwave oven, heat is quickly generated and evenly distributed throughout the food item, as the inner molecules boils and the generated steam heats the adjacent solids by conduction and is lost to the outside (Girard, 1991), causing greater water loss compared with direct heating methods. However, in the present study, as soon as the internal temperature of the meat reached $72{ }^{\circ} \mathrm{C}$, heating was interrupted, minimizing water loss to the outside.

The results of the present study are partially different from those obtained by Rosa et al. (2006), who compared different cooking methods (immersion in water, conventional oven, grill, microwave oven, and deep frying) of chicken breast and leg, and observed greater cooking weight loss with a microwave oven (32.49\%), followed by deep frying (29.18\%), and the lowest cooking weight loss (CWL) when samples were cooked in a grill (23.46\%).

The higher cooking weight loss found by Rosa et al. (2006) using a microwave may be explained by cooking time, which was 10 minutes for breast samples and 12 minutes for leg samples - longer than that used in 
this study. In addition, those authors do not report the internal temperature measurements, which might have been higher than $72^{\circ} \mathrm{C}$, leading to greater evaporation of meat components. Moreover, inner fillets are cut differently from conventional chicken carcass parts, which may also have influenced the result.

The results of the present study partially corroborate the findings of Vieira (2005), who compared chicken fillets cooked in water, deep fried, and roasted in a conventional oven or in a microwave oven, and reported lower cooking weight losses in deep-fried and water-cooked samples.

According to Califano et al. (1997), in meat products heated between $40^{\circ} \mathrm{C}$ and $60^{\circ} \mathrm{C}$, there is considerable actin denaturation, and this effect is responsible for the loss of fluids that occurs in the product. However, literature defines meat cooked at internal temperatures of $60^{\circ} \mathrm{C}$ as "rare", $71^{\circ} \mathrm{C}$ "medium" and $77^{\circ} \mathrm{C}$ "well done" (Savell et al., 1998), indicating greater water losses when meat is cooked at higher temperatures. The highest cooking loss obtained with the deep frying method in the present study may be explained by the high temperature to which the samples were exposed to, leading to greater protein denaturation and, consequently, greater meat fluid loss.

The greater differences in malonaldehyde concentrations between fresh and cooked chicken inner were obtained with the deep frying and microwave oven methods $(p<0.05)$. The lowest difference was calculated when samples were grilled (Table 2), whereas the values of samples cooked in water bath and in electric oven were not different $(p>0.05)$ from the other treatments.

Table 2 - Values of the differences in malonaldehyde concentrations of chicken inner fillets of assay I (fresh and cooked) and assay II (cooked and reheated)

\begin{tabular}{|c|c|c|}
\hline & \multicolumn{2}{|c|}{ Malonaldehyde (mg/kg) } \\
\hline & Difference* & Difference** \\
\hline Water Bath & $0.1621^{a b}$ & $0.2222^{b}$ \\
\hline Electric Oven & $0.1293^{a b}$ & $0.0763^{b}$ \\
\hline Microwave Oven & $0.1783^{a}$ & $0.6533^{a}$ \\
\hline Deep Frying & $0.1871^{a}$ & $-0.0291^{b}$ \\
\hline Grilling & $0.0989^{b}$ & $0.0570^{b}$ \\
\hline Mean & 0.1511 & 0.1959 \\
\hline $\mathrm{SEM}^{* * *}$ & 0.0080 & 0.0451 \\
\hline$p$ Value & 0.0022 & $<0.0001$ \\
\hline
\end{tabular}

${ }^{*}$ Assay I - Difference: cooked - fresh ** Assay II - Difference: reheated - cooked

$* * *$ Standard Error of the Mean.

Means in the same column followed by different lowercase letters significantly differ by Tukey's test $(p \leq 0.05)$.

The microwave oven cooking method caused greater oxidation possibly because it is directly linked to reactions of fat oxidation initiation. Lipid oxidation consists of three main phases: initiation, propagation, and termination (Sevanian \& Hochstein, 1985), and in meats, fat oxidation initiation reactions can take place through the actual thermal degradation of organic matter or by using microwave ovens by energy absorption (Ferrari, 1998).

Deep frying also promoted high lipid oxidation differences between fresh and cooked inner fillets, and may be explained by actual autoxidation, which is the main mechanism of oxidation of oils and fats (Berger \& Hamilton, 1995). Therefore, immersing meat samples in oil likely increases lipid levels in their composition, causing greater lipid oxidation in the samples subjected to the deep frying process. In order to prevent oil autoxidation, the incidence of all factors that favor it must be reduced, lowering as much as possible the levels of temperature and light (Ramalho \& Jorge, 2006). However, it is essential to increase the temperature when oils are used for cooking, which may add up to the change in lipid oxidation when foods are deep fried, as it combines the high temperature of the cooking process with the greater availability of fatty acids susceptible to oxidation (Silva, 2013).

The oxidation processes during cooking are more influenced by long cooking time and lower temperature than by short cooking time and higher temperature (Broncano et al., 2009). Because the samples cooked in the microwave oven presented higher levels of oxidation compounds, despite the low temperature and short time, it is suggested that there may be an effect of the microwave oven on meat fat that causes oxidation of polyunsaturated fatty acids (Broncano et al., 2009), which may explain the increase in lipid oxidation observed in the microwave oven cooking process. Broncano et al. (2009), analyzing the Latissimus dorsi muscle of pigs treated with different cooking methods, determined that cooking in microwave oven caused slightly lower lipid oxidation compared with frying and roasting, as partially observed in the present study.

Some enzymes can inhibit lipid oxidation, such as glutathione peroxidase, which catalyzes the reduction of organic hydroperoxides, protecting lipoproteins and cell membranes. However, the activity of glutathione peroxidase, as well as that of most enzymes, is reduced as heating temperature increases, which may lead to greater lipid oxidation of food items, regardless of cooking method (Thomas, 1990; Arthur, 2000), as detected by the current results.

The differences in malonaldehyde concentrations between the cooked and reheated samples was greater 
$(p<0.05)$ in inner fillets cooked in the microwave oven compared to the other treatments (Table 2).

TBARS values greater than $1 \mathrm{mg}$ of malonaldehyde per $\mathrm{kg}$ of sample are perceptible, as they cause off flavors (Djenane et al., 2002). The samples that showed values near $1 \mathrm{mg}$ were those cooked and reheated in the microwave oven. The results showed that cooking in a microwave oven was the process that most influenced (60.21\%) lipid oxidation when the chicken inner fillets were reheated, compared to the fresh samples.

Cooking is one of the main causes of lipid oxidation of meat products, and protein denaturation occurs during this process due to heating. However, when reheating pre-cooked meats, the chelation of denaturated proteins releases active iron, which acts as a catalyzer of oxidation reactions that areresponsible for the development of warmed over flavor in reheated meats (Igene et al., 1980).

The different freeze/thaw cycles (Table 3) influenced $(p<0.05)$ meat $\mathrm{pH}$ values. The $\mathrm{pH}$ values obtained after the first cycle were lower (6.03) compared with to the other freezing cycles. On the other hand, from the fourth freezing cycle, $\mathrm{pH}$ values remained unchanged, indicating $\mathrm{pH}$ stabilization.

Table 3 - Mean pH, malonaldehyde concentration, myofibrillar fragmentation index (MFI) and water retention capacity (WRC) values of chicken inner fillets subjected to different freeze/thaw cycles

\begin{tabular}{lcccc}
\hline Freeze/thaw cycles & $\mathrm{pH}$ & $\begin{array}{c}\text { Malonaldehyde } \\
(\mathrm{mg} / \mathrm{kg})\end{array}$ & $\mathrm{MFI}(\%)$ & WRC (\%) \\
\hline 1 cycle & $6.03^{\mathrm{b}}$ & $0.1439^{\mathrm{c}}$ & $58.51^{\mathrm{c}}$ & $63.06^{\mathrm{c}}$ \\
4 cycles & $6.22^{\mathrm{a}}$ & $0.4035^{\mathrm{b}}$ & $63.57^{\mathrm{b}}$ & $64.10^{\mathrm{b}}$ \\
\hline cycles & $6.25^{\mathrm{a}}$ & $0.4909^{\mathrm{a}}$ & $67.65^{\mathrm{a}}$ & $65.21^{\mathrm{a}}$ \\
Mean & 6.17 & 0.3461 & 63.24 & 64.13 \\
SEM $^{*}$ & 0.02 & 0.0159 & 0.47 & 0.19 \\
\hline p Value & $<0.0001$ & $<0.0001$ & $<0.0001$ & $<0.0001$ \\
\hline
\end{tabular}

* Standard Error of the Mean. Means in the same column, followed by different lowercase letters, differ significantly by Tukey's test $(p \leq 0.05)$.

These results are different from those obtained by Ali et al. (2015), who analyzed the influence of freezing cycles (six cycles) on the pH of chicken breast fillets and observed that $\mathrm{pH}$ decreased as freezing cycles increased.

Freeze/thaw cycles significantly affected water retention capacity (WRC). The highest values were found in the inner fillets subjected to eight freeze/ thaw cycles, and the lowest values in those frozen and thawed only once. The inner fillets that were frozen four times differed from the remaining treatments. When studying the effect of freezing on chicken meat, Hernandez (2005) obtained lower WRC values in fresh meat. It is known that WRC is influenced by general factors, among which the most important are $\mathrm{pH}$ and myofibrillar fragmentation index (MFI) (Forrest et al., 1979), and it is defined as the capacity of meat to retain its own water during the application of external forces, such as freezing. Consequently, it is assumed that the stronger the external forces applied on the meat, the lower is its water retention capacity.

Lower WRC and $\mathrm{pH}$ values when determined in the inner fillets subjected to eight freezing cycles, confirming the positive correlation between these variables (Ngapo et al., 1999; Zapata et al., 2006) and suggesting that higher $\mathrm{pH}$ values increase the capacity of the meat to retain water.

The myofibrillar fragmentation index (MFI) is frequently used in meat quality assessments, as it predicts more than $50 \%$ of the variation in meat tenderness (Hopkins et al., 2000; Veiseth et al., 2001). In the present study, the samples were not large enough to determine shearing force or sensorial characteristics. MFI values were different $(p<0.05)$ among the evaluated freezing cycles, and increased as the number of freeze/thaw cycles increased. According to Culler et al. (2009), meats with MFI values higher than 60 are considered to have satisfactory texture, and overall, the MFI values determined in the present study were close the recommended value (average 63.24).

The fragmentation of myofibrils caused by autolysis and the severity of the cold/heat cycles may have influenced the increase in WRC, given that the $\mathrm{pH}$ did not show significant differences between treatments following thawing/freezing cycles.

Malonaldehyde level increased $(p<0.05)$ as the number of freeze/thaw cycles increased, with the highest values of malonaldehyde found when subjected to eight freezing cycles, followed by four, and one freeze/thaw cycle. These results are consistent with those of Ali et al. (2015), who studied the effect of freeze/thaw cycles (six cycles) on lipid oxidation and observed a considerable increase in the concentration of malonaldehyde in thawed chicken breasts after the fourth freeze/thaw cycle, and even greater concentrations after the fifth and sixth cycles.

Research on cooking methods and freezing cycles of meat products are still scarce, which emphasizes the importance of studies evaluating the effect of thermal processing methods on meat products in order to disseminate that knowledge to the public, as well as to reduce the consumption of oxidized food items by consumers, considering that meat cooking and freezing are also household processes. 


\section{ACKNOWLEDGMENTS}

The authors thank FUNDECT (Fundação de Apoio ao Desenvolvimento do Ensino, Ciência e Tecnologia do Estado de Mato Grosso do Sul) for granting a scholarship to the first author.

\section{CONCLUSION}

Deep frying and cooking in a microwave oven are the cooking methods that cause the highest lipid oxidation in chicken inner fillets. Cooking weight loss is the highest when the fillets are deep fried.

When reheating chicken inner breast fillets, the use of microwave oven increases lipid oxidation.

The three freeze/thaw cycles (one, four and eight cycles) increase meat $\mathrm{pH}$, water retention capacity, myofibrillar fragmentation index, and lipid oxidation, impairing the quality of broiler chicken inner fillets.

\section{REFERENCES}

Ali S, Zhang W, Rajput N, Khan MA, Li CB, Zhou GH. Effect of multiple freeze-thaw cycles on the quality of chicken breast meat. Food Chemistry 2015;173:808-814.

Angelo AJSt, Vercellotti J, Jacks T, Legendre M. Lipid oxidation in foods. Critical Reviews in Food Science and Nutrition 2009;36(3):175-224.

Araújo C. Transmissão de calor. 2nd ed. Rio de Janeiro: LTC; 1982.

Arthur JR. The glutathione peroxidases. Cellular and Molecular Life Sciences 2000;57:1825-1835.

Benjakul S, Visessanguan W, Thongkaew C, Tanaka M. Comparative study on physicochemical changes of muscle proteins from some tropical fish during frozen storage. Food Research International 2003;36(8):787795.

Berger KG, Hamilton RJ. Lipids and oxygen: is rancidity avoidable in practice. In: Hamilton RJ, editor. Developments in oils and fats. Londres: Springer; 1995. p.269.

Bobbio PA, Bobbio FO. Química do processamento de alimentos. 2nd ed. São Paulo: Varela; 1995.

Broncano JM, Petrón MJ, Parra, V. Timón ML. Effect of different cooking methods on lipid oxidation and formation of free cholesterol oxidation products (COPs) in Latissimus dorsi muscle of Iberian pigs. Meat Science 2009;83(3):431- 437.

Brossi, C. Qualidade de carne de frango: efeito do estresse severo pré-abate, classificação pelo uso da cor e marinação [dissertation]. Piracicaba (SP): Escola Superior de Agricultura Luiz de Queiroz; 2007.

Califano NA, Bertola NC, Bevilacqua AE, Zaritzky NE. Effect of processing conditions on the hardness of cooked beef. Journal of Food Engineering 1997;34(1):41-54.

Culler RD, Parrish JRFC, Smith GC, Cross HR. Relationship of myofibril fragmentation index to certain chemical physical and sensory characteristics of bovine longissimus muscle. Journal of Food Science 2009;43(4): 1177-1180.
Djenane D, Sanchez-Escalante A, Beltrán JA, Roncalés P. Ability of $\alpha$ tocopherol, taurine and rosemary, in combination with vitamin $C$, to increase the oxidative stability of beef steaks packanged in modified atmospheres. Food Chemistry 2002;76(4):407-415.

Ferrari CKB. Oxidação lipídica em alimentos e sistemas biológicos: mecanismos gerais e implicações nutricionais e patológicas. Revista de Nutrição 1998;11(1):3-14.

Forrest JC. Fundamentos de ciencia de la carne. Zaragoza: Acribia; 1979.

Girard JP. Tecnologia de la carne y los productos cárnicos. Zaragoza: Acribia;1991.

Hernández AJR. Efecto Del método de congelamiento sobre lãs características fisicoquímicas y organolépticas de La carne de pechuga de pollo [dissertation]. San Juan (PR): Universidade de Porto Rico; 2005.

Hopkins DL, Littlefield PJ, Thompson JM. A research note on fators affecting the determination of myofibrillar fragmentation. Meat Science 2000;56(1):19-22

Igene JO, Pearson AM, Dugan JRLR, Price JF. Role of triglycerides and phospholipids on development of rancidity in model meat systems during frozen storage. Food Chemistry 1980;5(4):263-276.

Lakshmanan R, Parkinson JA, Piggott JR. High-pressure processing and waterholding capacity of fresh and cold-smoked salmon (Salmo salar). LWT- Food Science and Technology 2007;40(3):544-551.

Lopes Comercial. Filezinho de Peito (Sassami) [cited 2015 Jul 20]. 2014. Available from: http://www.lopescomercial.com.br/Produto/36185/ filezinho-de-peito-sassami-.

Luciano G, Monahan FJ, Vasta V, Pennisi P, Bella M, Priolo A. Lipid and colour stability of meat from lambs fed fresh herbage or concentrate. Meat Science 2009;82(2):193-199.

Ngapo TM, Babare IH, Reynolds J, Mawson RF. Freezing and thawing rate effects on drip loss from samples of pork. Meat Science 1999;53(3):149158.

Pavan AC, Mendes AA, Oliveira EG, Denadai JC, Garcia RG, Takita TS. Efeito da linhagem e do nível de lisina da dieta sobre a qualidade da carne do peito de frangos de corte. Revista Brasileira de Zootecnia 2003;32(6):1732-1736

Pearson AM, Love JD, Shorland FB. "Warmed-over flavor" in meat, poultry, and fish. New York: Advances in Food Research; 1977.

Potter NN, Hotchkiss JH. Ciência de lós alimentos. 5th ed. Zaragoza: Acribia; 1995.

Ramalho VC, Jorge N. Antioxidantes utilizados em óleos, gorduras e alimentos gordurosos. Química Nova 2006;29(4):755-760.

Rosa FC, Bressan MC, Bertechini AG, Fassani EJ, Vieira JO, Faria PB, et al. Efeito de métodos de cocção sobre a composição química e colesterol em peito e coxa de frangos de corte. Ciência e Agrotecnologia 2006;30(4):707-714.

SAS. SAS university edition: installation guide for OS X. Cary: SAS Institute; 2014.

Savell JW, Smith GC. Laboratory manual for meat science. 6th ed. Boston: American Press; 1998.

Sevanian A, Hochstein P. Mechanisms and consequences of lipid peroxidation in biological systems. Annual Review of Nutrition 1985;5:365-390.

Silva CE. Elaboração e avaliação de hambúrgueres de carne bovina com substituições de toucinho por farinha de linhaça [dissertation]. Londrina(PR): Universidade Tecnológica Federal do Paraná; 2013. 
Thomas JP, Maiorino M, Ursini F, Girotti AW. Protective action of phospholipid hydroperoxide glutathione peroxidases against membrane-damaging lipid peroxidation. In situ reduction of phospholipids and cholesterol hydroperoxides. Journal of Biological Chemistry 1990;265(1):454-461.

Veiseth E, Shackelford SD, Wheller TL, Koohmaraie M. Technical note: comparison of myofibril fragmentation index from fresh and frozen pork and lamb longissimus. Journal of Animal Science 2001;79(4):904906.

Vieira JO. Métodos de cocção na composição centesimal, colesterol e perfil de ácidos graxos do peito de frangos criados no sistema convencional e alternativo [dissertação]. Lavras (MG): Universidade Federal de Lavras; 2005.
Vyncke W. Direct determination of the thiobarbituric acid value in trichloroacetic extracts of fish as a measure of oxidative rancidity. FetteSeifen Anstrichmittel 1970;72(12):1084-1087.

Willemot C, Poste LM, Salvador J, Wood DF. Lipid oxidation in pork during warmed over flavor development. Canadian Institute of Food Science and Technology Journal 1985;8(4):316-322.

Zapata JFF, Andrade AA, Assunção GM, Barrteo CSC, Abreu VKG. Avaliação preliminar do armazenamento em congelamento sobre a qualidade da carne de peito de frango de dois tipos genéticos. Brazilian Journal Food Technology 2006;9(3):185-191 
